\title{
INTERSTITIAL EMPHYSEMA AND PNEUMOTHORAX ASSOCIATED WITH THE USE OF A MODIFIED NON-REBREATHING VALVE
}

\author{
Harold T. Davenport, F F.A R.c.s, and H, B. Klaenleyside, M D. *
}

THE IDEA of using non-rebreathing systems recurred throughout the first hundred years of anaesthesia, and special interest has been slown at the start of the second hundred years in valvular non-rebreathing apparatus, particularly in paediatric work

This trend was encouraged by Drs. Leigh, Stephen and Slater at Montreal, who designed valves which have improved function

Recently, much ingenuity has been expended in devising newer non-rebreathing valves $(1,2,3,4,5,6)$ which facilitate the control or assistance of respiration by automatic closure of the expiratory valve during positive pressure inspiration

Very recently, the extension of the scope of surgery in paediatrics has encouraged the use of newer agents previously reserved for adult work. Some leaders in the field of paediatric anaesthesia have also favoured the use of these agents. Depression of respiration may thus become commonplace in small patients, and it is probable that the newer non-rebreathing valves may be considered a boon in such circumstances, it is therefore worthwhle drawing attention to a certain danger. The small volume and delicate structure of the small patient's lungs make traumatic pneumothorax and interstitial emphysema more likely to occur if any undue pressure is exerted withm the respiratory tract There is a considerable danger with all of the modified non-rebreathing valves so far produced that such excessive pressure will be transmitted directly to the lungs This is well illustrated by the following case history

\section{Case Report}

Wendy W, aged 6 years, weight $34 \mathrm{lbs}$, was healthy apart from congenital deformation of the right hand which was to be corrected by plastic surgery

Medication given one hour before operation consisted of Demerol, $25 \mathrm{mgm}$, and scopolamine, $1 / 300 \mathrm{gr}$

Anaesthesia was induced by $6 \mathrm{ml}$ of Bairds Solution (that 15 , thropentone, $150 \mathrm{mgm}$, and d-tubocurare, $45 \mathrm{mgm}$.) given intravenously, and the patient was ventilated gently with oxygen for $113 \mathrm{~mm}$, using a circle absorber system with a leakng valve A Portex endotracheal tube no 25 French gauge was easily inserted orally, but some "bucking" followed

The endotracheal tube was attached to the corrugated tubing of a Magill attachment by means of a Fink valve ( $F_{1}$. I) A gas flow of nitrous oxide, 5 litres/mm, plus oxygen, 3 litres/min, was turned on and the endotracheal tube and adjacent oral arrway secured to the lips Immediately it was noticed that the chest was inflated fully, but the reservoir bag was only partly filled with gas

The Fink valve was disconnected and a rush of gas escaped from the tube connector The typical appearance and feel of massive subcutaneous emphysema of the neck, face and chest were then evident The extremities and face appeared a cyanotic grey colour and there was difficulty in palpation of the radial pulse

As the child had little spontaneous respiration, it was necessary to assist respuration gently by means of a face mask (connected to the Magll attachment) over the endotracheal tube,

"McGill University, Montreal, P Q 

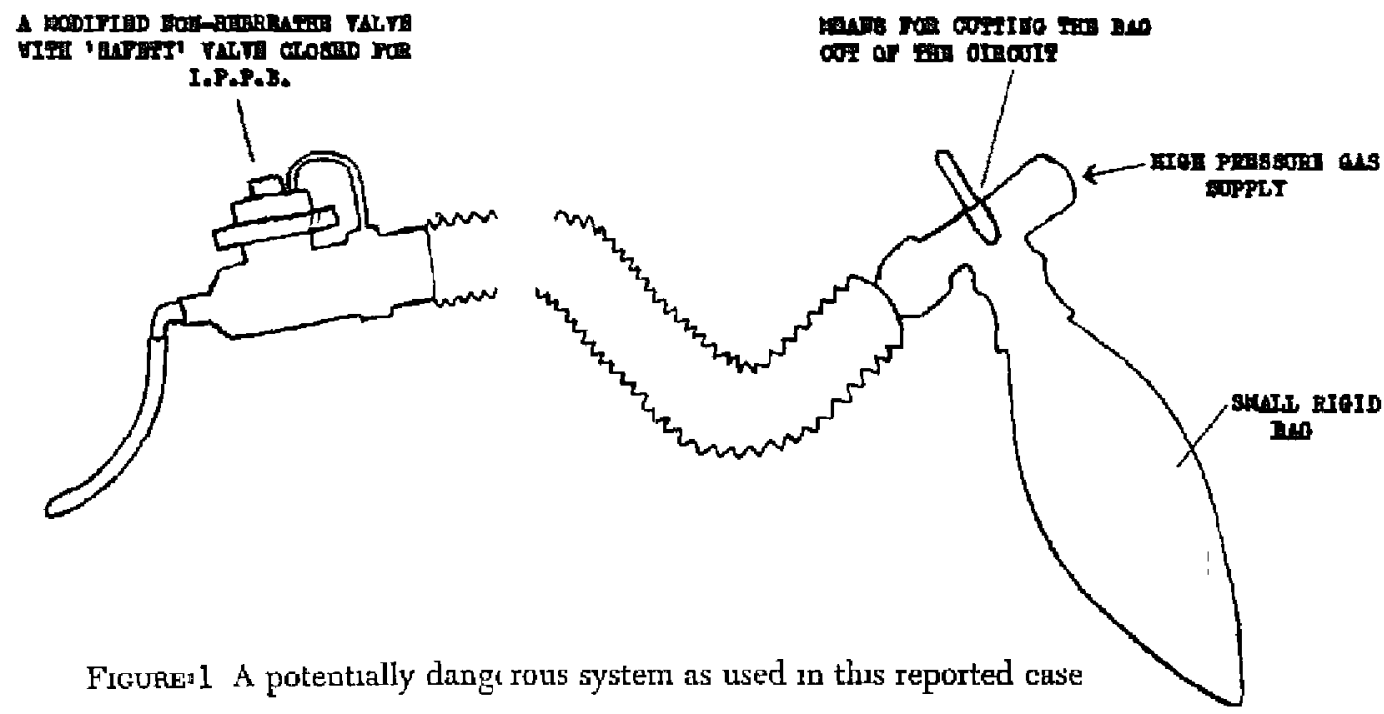

Fieurej1 A potentially dangi rous system as used in this reported case

it was then noticed that the resirvor bag of thrs attachment had been excluded from the circuit unintentionally

As the child's condition was critical, a needle was placed into both pleurnl cavitues and air aspirated, the needles were then attached to water seal bottles and more gas escaped from both sıdes In case the stomach had becane distended and would further embnriass respiration, a Levine tube was passed A portable Rontgenogran was then obtaned (Fug 2) The systolic

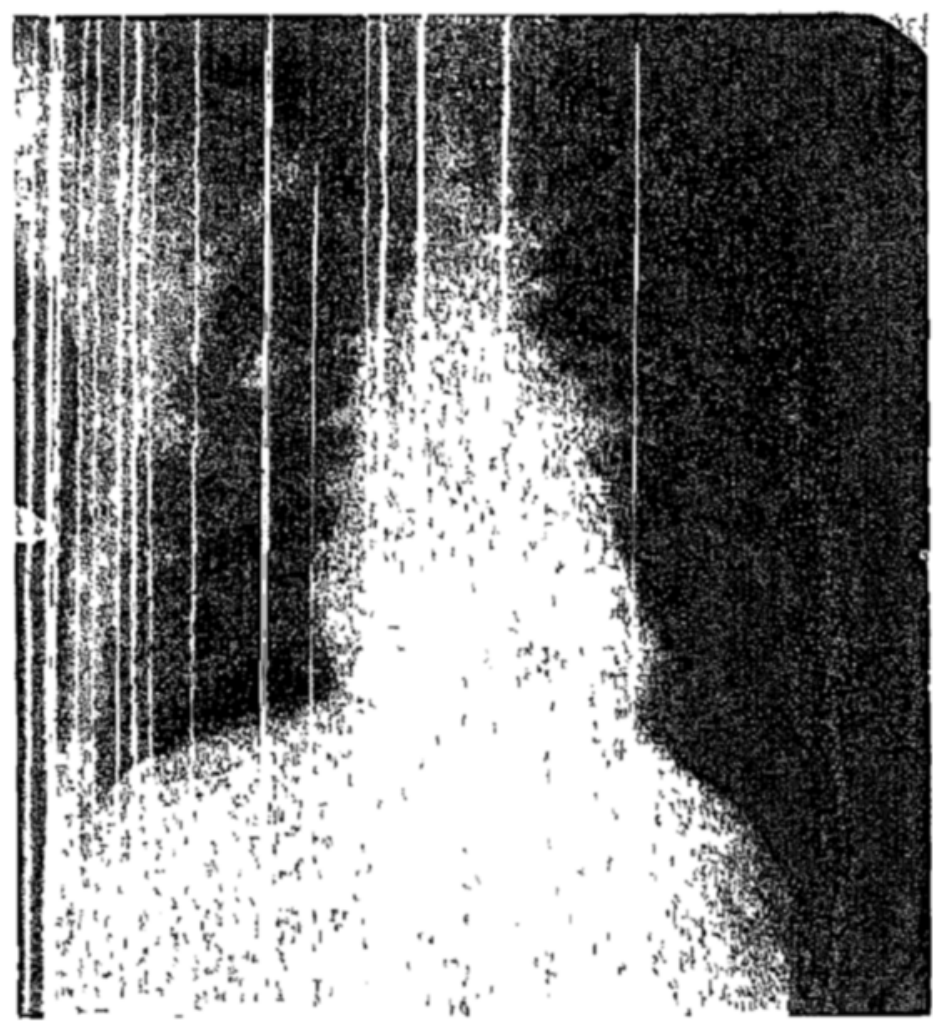

Ficunx 2 Rontgenogram taken with a portable machine 30 minutes after the incudent Bilateral pneumothorax, nore marked on the right, and interstitial emphysema of the mediastinum and neck Needles in place in each side of the thorax and an opaque rubber tube with its top in the stornach 
blood pressure rose from $100 \mathrm{~mm} \mathrm{Hg}$ to $160 \mathrm{~mm} \mathrm{Hg}$ and the pulse rate from 90 to $160 / \mathrm{mm}$ during the hypoxic period which lasted about 30 minutes while spontaneous respiration was inadequate. The proposed operation was cancelled

The child's condition improved continuously and after conserousness had been regained the intrapleural needles were removed one at a tıme, the child was extubated, and X-ray used to check the extent of the pneumothoraces

The patzent remained in an oxygen tent for $6 \mathrm{hr}$, and the blood pressure returned to normal within $2 \mathrm{hr}$, but the pulse rate cid not return to normal for $8 \mathrm{hr}$. Two days after the incident the mediastinal emphysema had disappeared and the chuld was quite well agam.

Four subsequent operations were performed, the first being 35 days later Each tume the precaution was taken to maintain spontaneous respiration, and nothing unusual occurred

Obviously, the explanation of this accident was that the safety outlet on top of the Fink valve was closed in readiness for assisting respiration, and the gas supplied to the flowmeter (approxımately $200 \mathrm{~mm}$. Hg.) exerted its pressure directly within the respiratory tract without any means of escape, until rupture occurred somewhere within the lungs and bilateral pneumothorax and massive mediastinal and subcutaneous emphysema ensued The exclusion of the reservorr bag and the high total flow of gases gave rise to dangerous intrathoracic pressure in the small patient in a minımum of time Owing to paralysis of the patient with curare intermittent positive pressure respiration was contmued and both the tension pneumothoraces and emphysema were aggravated to a near fatal degree

\section{Discussion}

If compressed gases are to be directed to the respuratory tract of patients, the necessity of a thorough understanding of the danger involved cannot be overemphasized. The final pressure at the point of delivery must be greatly reduced to be manageable; with some anaesthetic and resuscitation apparatus this is not possible. The latest reported incidents which are similar to that above have usually involved children who have been intubated $(7,8,9,10)$ The safety factor provided by leakage around a small tube was recognized long ago (11), as was the reduced danger if a low rate of flow of gas was used. As modern ideas encourage a snugly fitting tube and high rate of gais flow it is likely that overinflation may occur more often. Recently it has been reasoned that the point of rupture of the lung will depend on tissue stretch rather than absolute pressures Thus, for instance, the maximal safe pressure will be less if the chest is opened or if voluntary or reflex tensing of expiratory muscles is reduced (12) Until the safe intrabronchial pressure permissible in humans under various conditions is discovered we must, for practical purposes, accept the limit of $18 \mathrm{~mm} \mathrm{Hg}$ set by Marcotte et al. (13) and earlier workers.

The modified non-rebreathing valves so far described need extremely cautious use in work with children, as no provision is made for accurately controlling the maximum pressure at which they will blow off if the gas flow should exceed minute volume or active expiration be obtunded A large distendible reservoir bag is preferable because of the increased time it provides before pressure builds up in case of accidents and during expiration. As it is rarely necessary to cut out the reservoir bag, the device sometimes provided fo- this purpose should be eliminated. Owing to wide variation in the minute vo-ume of younger patients, it is not possible for the anaesthetist always to adjust an exact gas flow to prevent 
the minute volume from being exceeded and yet not have the bag become empty on inspiration. Especially in paediatric work, an arrangement should always be used which will limit the intrathoracic pressure and indicate its degree. Such a "pop-off" arrangement must be finely graduated so that it can be set for any maximal pressure that is desired and it should never be possible to close it completely, and it must be easily accessible and foolproof. The newer non-rebreathing valves with their complicated mechanism are more liable to go wrong, and if it is desired to free one hand of the anaesthetist, it may be safer to use a high flow partial rebreathe technique (Fig. 3), or a semi-closed carbon dioxide absorption system with a controllable "leak."

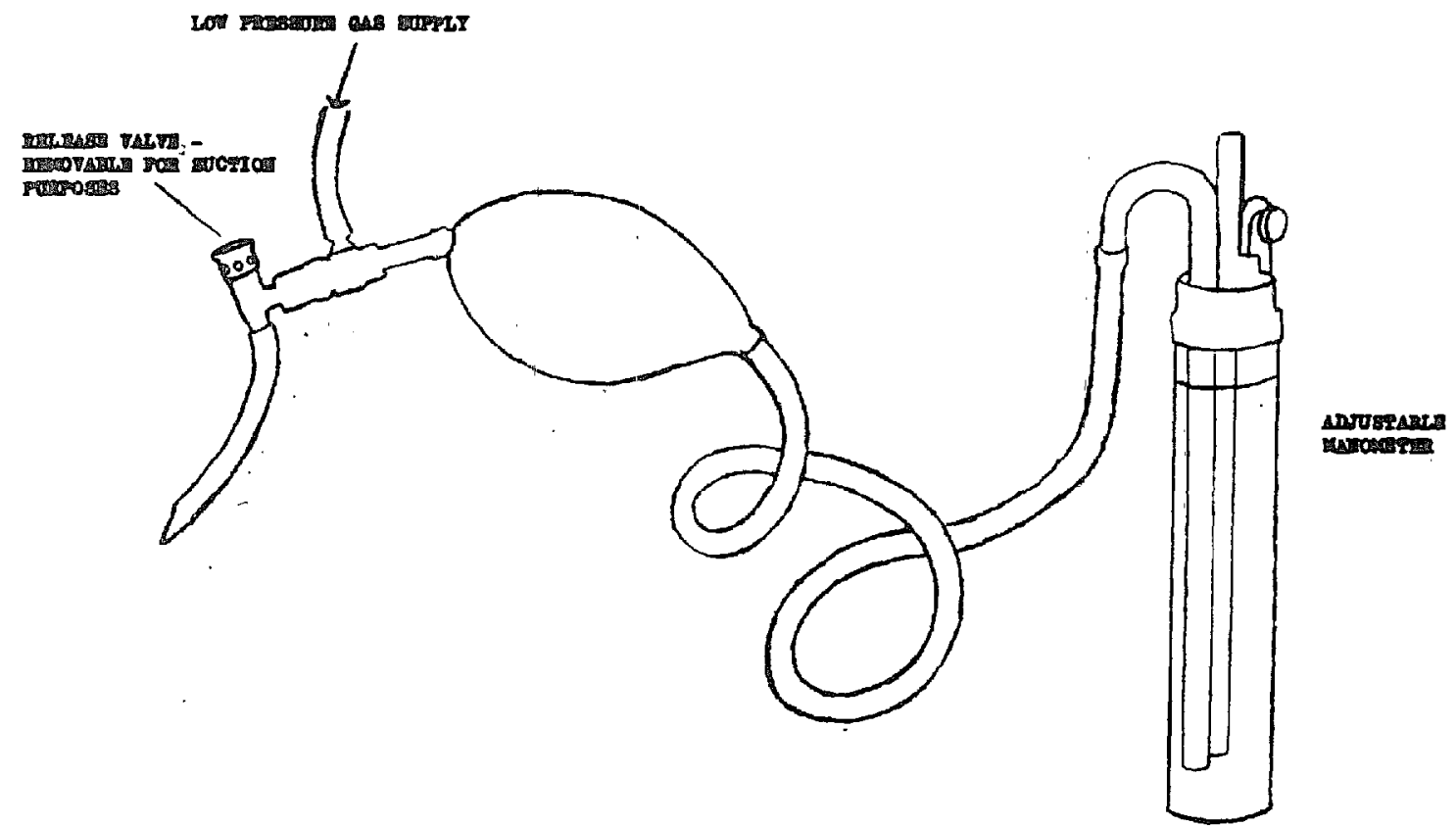

Figure 3. A sinfiple safe system for intermittent positive pressure breathing in small children.

"Temporary discarding of the safety valve and manometer" led to one of the first deaths reported during endotracheal anaesthesia (14). Woolsey then commented that such "unfavourable results, have their origin in easily remedied faults of technique," and 45 years later we fully endorse his statement.

\section{SUMMARY}

Increase of intrathoracic pressure to a dangerous level is probable when some modified non-rebreathing valves are used under certain circumstances.

A description of a near fatality due to bilateral pneumothorax and massive interstitial emphysema is presented, which illustrates this danger.

Unfamiliarity with some apparatus which may be completely closed intermittently by an automatic deviee may be particularly dangerous with children who are intubated and have increased compliance of the pulmonary system.

\section{ACKNOWLEDGMENT}

Our thanks are due to Dr. Gordon Petrie and Dr. Wesley Bourne (surgeon and anaesthetist at the Shriners' Hospital of Montreal) for permission to report a part of the medical history of their patient. 


\section{RÉSUMÉ}

L'augmentation de la pression intrathoracique peut devenir dangereuse dans certaines conditions particulières, lors de l'emploi de types modifiés de valves à crrcuit sans réinspiration

Les auteurs rapportent le cas d'un enfant de six ans se présentant à la chirurgie pour correction plastique de malformation congénitale de la main. Une fois intubé, avec un tube endotrachéal type Portex, réuni au tube d'un appareil de Magill par l'entremise d'une valve de Fink, l'eafant développa un pneumothorax bilatéral et un emphysème interstitiel massif au toul débout d'une anesthésie au protoxyde d'azote, cinq litres $/ \mathrm{min}$. et oxygène, trois litres $/ \mathrm{mm}$. La soupape d'échappement d'urgence de la valve de Fink avalt été fermée dans l'intention d'assister la respuration, la pression de gaz indıquée au débitmètre (approximativement $200 \mathrm{~mm} \mathrm{Hg}$ ) se trouva donc transmise directement aux parois internes des voies respiratorres sans possibılıté d'échappement, jusqu'à provoquer la rupture du poumon en un point quelconque avec le résultat décrit précédemment L'exclusion involontaire du ballon, associée à un débit élévé de gaz, conduit, en un court espace de temps, à la création de pressions intrathoraciques dangereuses chez ce petit malade

L'usage trop peu fréquent de certans appareils qui peuvent être complètement et automatiquement fermés peut devenir particulièrement dangereux chez des enfants qui sont intubés et ont une "compliance" pulmonaire augmentée

\section{REFERENCES}

1 Flach, V A \& Voss, G Zur Kunstlichen Beatmung im Halboffenen System Der Anaesthesist, 4210 (1954)

2 Fink, B R A Nonrebreathing Valve of New Design Anesthesiology, 15471 (1954)

3 Ruben, H A New Nonrebreathing Valye Anesthesiology, 16 643 (1955)

4 Newton, G W, Nowill, W $\mathrm{K}$ \& Stephens, C R A Piston-Type Nonrebreathing Valve Anesthesiology, 161037 (1955)

5 Lewis, G Nonrebreathing Valve Anesthesiology, 17618 (1956)

6 Shuman, R C Modified Nonrebreathing Valve Anesthesiology, 17749 (1956)

7. Rollason, W N. Massive Surgical Emphysema Occurring under General Anaesthesia Anaesthesia, 6 112 (1951)

8. SFENCE, M Surgical Emphysema during Anaesthesia Anaesthesia, 1050 (1955).

9 Ozinskx, J \& Butr, A. B Surgical Emphysema as a Complication of Anaesthesia. Bnt Med J, 1. 460 (1955)

I0 Ohio Study Commission Report Pneumothorax Recovery Anesthesia Digest, 1553 (1955)

11 Eisensbey, A B Observations on the Use of Intratracheal Anaesthesia in Expenmental Work. Surg, Gynec. \& Obst, 15715 (1912)

12 WhtTtEnberger, J L Resuscitation and Other Uses of Artificial Respiration New Eng $\mathrm{J}$ Med, 251775 (1954)

13 Marcotte, R J, Philitis, F J, Adams, W E \& Livingstone, H M Differential Intrabronchial Pressures \& Mediastinal Emphysema J Thoracic Surg, 9346 (1940)

14 Woolsey, W C Intratracheal Insufflation Anaesthesia N Y State J Med, 12167 (1912) 